\title{
MICHAEL PHILIP WEST AS A FOUNDER OF TEACHING READING METHODOLOGY
}

\author{
Dilnoza Saimnazarova Abdune`matovna \\ Tashkent state pedagogical university \\ named after Nizami
}

Article DOI: https://doi.org/10.36713/epra2316

\begin{abstract}
The article deals with the problems of reading texts in foreign languages (English texts) and the role of Michael Philip West's investigations on reading issues. Scientific and practical considerations set forth in the teaching methodology of M. West have played a leading role in solving this problem throughout the world. The ideas of M. West were enriched with new methodological information about training in different countries.
\end{abstract}

KEY WORDS: method, methodology, direct method, grammar translation method, receptive and (re)productive speech, text adaptation, active/passive vocabulary, types of reading, reading comprehension.

\section{DISCUSSION}

Nowadays as fluent readers we read plenty different types of texts, some that we intentionally aspire to read, and some that we just seem to pick up or encounter. We read what in modern societies because print is all around us, we use it in many more ways than we are aware of. We read magazines during the day, whether to enjoy, relaxing or waiting in some office. We read newspapers, ads, posters. We also read at night before going to sleep. We read when we look at products while shopping. We read billboards, posters and displays when we travel on different kind of public transportation. We read forms in order to fill them out. We read when we receive and send e-mails and text messages, and when we search the Web for information. [9:5]

In William Grabe's words (2009) in more formal settings, we expect to read in academic contexts or in workplace environments as part of learning or engaging in our job. Many of us also engage in reading that may be quite demanding in educational, professional, and occupational settings. In these latter settings, a great deal of learning occurs; part of that learning requires that we engage in and the goals that we set (or that are set for us). These settings often require us to synthesize, interpret, evaluate, and selectively use information from texts. [9:5]

The process of reading is characterized with reading dynamic, i.e. the progress of reading in time. It depends much on the achieved level of language competence and the reading skills. The type of the text is also a factor in the dynamics of reading.[7:161]

This article focuses on reading as a component of general foreign language proficiency, but reading must be considered only in the perspective of the whole picture of interactive language teaching. Moreover, the article retrospectively describes the methodology of teaching foreign languages within the framework of research of the English scientistmethodologist Michael Philip West.

As in each sphere, there are theorists and outstanding classics of the methodology of teaching foreign languages, who have made great contribution to the development of this aspect. They are English professors Michael Philipp West, Harold Edward Palmer, American professors Charles Carpenter Friz, Robert Lado, Russian professors Igor Vladimirovich Rakhmanov, Valentina Samuelna Setlin, Uzbek professors Jalalov Jamol Jalalovich, Gulnora Turdiokhunovna Mahkamova, Tojimat Kodirovich Sattorov etc.

As we know, in every field there are leading specialists. When it comes to English methodology on the problem of teaching reading it is worth mentioning Michael Philipp West's great works.

At present, an English learner should know four types of speech activities: listening, speaking, reading and writing. A century ago Michael West carried out very important scientific researches, not only theoretically, but practically as well. He wrote several books about teaching reading in English language and created the theory of adaptation. 
Michael West was the first scientist who deeply and widely introduced teaching reading in English. The main purpose of the research is developing scientific point of view of Michael Philip West about teaching methodology of reading. We have studied West's point of views on this problem and we consider that he didn't study the interrelation of reading between listening, speaking and writing.

In late 1920 - 1930, during twenty years as an English teacher, Michael Philip West (1888-1973) created many theories about learning problems of English language. Although in the post-war years, Harold Edward Palmer drew a lot attention on teaching British and American English, as well as oral methodology, there were widespread problems of learning English and their importance in the theories of West.

After the World War I, in 1919, having examined the schools in Calcutta and Chittagong, M. West offered to implement comprehensive test on all teaching subjects. In fact, one of the features of $\mathrm{M}$. West's ideas about teaching English language were revised by the outstanding teachers of the educational service of India P.C. Wren and Horace Wyatt.

Michael West's conclusions on the problems of teaching English in Bengal were widespread: students spent 10 hours a week to learn English, but the results left much to be desired. For known reasons, that indicator reached "Matriculation" (i.e. until the last stage of high school). Even at this stage, the results were unsatisfactory. Only a few number of the students had the ability to read English, write very slowly and with difficulty [8].

In 1919, the Commission of the University of Calcutta proved the inefficiency of the existing education system. Despite the fact that all sciences at universities and colleges were taught in English, the students' proficiency level in English was not in required level to study at universities.

M. West argued about the views of the Commission, particularly, he rejected the opinion about the negative transfer of English language onto native language. [4]

M. West explained the following methods of teaching English language:

The student passes the "preparatory" stage of English language training. The "preparatory" stage means the ability to read a written text and the ability to understand English synonyms. This training is done with the help of the teacher. However, sometimes a teacher can give the equivalent of relevant words in Bengali language. In class, the teacher asks the student to read. The student continues to read for a long time. However, the learner cannot increase his/her knowledge of English. The teacher's attention is focused only on the student who is reading the text; he pays less attention to the rest of the class. During the reading, the student does not ask any questions. After finishing reading, the teacher gives feedback to the student. [8]

Moreover, M. West explained word-for-word translation as follows:

After giving the topic, the students were asked to translate the text once or twice a week. The topic was short and slightly difficult. Sometimes students translated texts using dictionaries and translated word for word and translations were carried out in written form in class.

The results were as follows:

- Children could not translate texts from English into their native language.

- They could not understand the content of the English version.

- They could not express their viewpoints in English.

"The direct method in Bengali schools failed because it required great skill of teachers." [4]

Uzbek professor J.J.Jalalov in his book, "Chet til o'qitish metodikasi": (Foreign language methodology) (2012) lays out the following thoughts on the researches of $M$. West and the methods developed by him:

As one of the founders of the receptive approach of the direct method, M. West had great scientific merits in teaching reading and speaking as well as in solving problems associated with the preparation of educational dictionaries. [5]

The methodological judgments of M. West in the issues of teaching colloquial speech in many respects resemble the judgments of $\mathrm{H}$. Palmer, i.e. in their works; the common views in this aspect are traced.

In the history of the world methodology on teaching reading $\mathrm{M}$. West has conducted worthy researches, his original insights into problems of teaching reading spread all over the world.

Due to the fact that the political worldview of M. West engaged in teaching Bengali children English, was imbued with nationalist ideas, he suggested small-scale nations necessarily have to teach one of the foreign languages, in his opinion, the English language. In this regard, the purpose of teaching foreign languages includes reading books and periodicals printed in English, assimilating the core content.

In designing the foreign languages courses, M. West proposed the following theory:

1. The receptive aspect of the language is considered as primary.

2. The positive reinforcement should be provided during reading texts.

3. To satisfy the needs of learners, two types of books for reading are offered. The first book should contain new materials for classroom use and 
the second one is for reading, based on the learned language material.

4. The content of texts should satisfy the learners' needs, interests, the age and should be attractive.

In the history of foreign languages teaching methodology adapting texts for reading was recognized as $M$. West's scientific invention. M West used the term "adaptation" in two forms: first shorten the material of the original text, and then simplify the language itself. [5]

In teaching the foreign language $\mathrm{M}$. West, supported the theory of $\mathrm{H}$. Palmer teaching a foreign language comparatively with the mother tongue. The scientist reasonably proved the methodological system of teaching reading by direct method.

M. West suggested reading of two types: the first type of reading requires reading words attentively; such reading sometimes is called "word by word reading", and the second type requires searching for detailed information, i.e. reading for the purpose of receiving information. $M$. West called the second type of reading "reading for gist".

Professor Jalalov in the methodology of FLT describes the qualities of a good reader as follows:

1. Read extensively.

2. Integrate information in the text with existing knowledge.

3. Have a flexible reading style, depending on what they are reading.

4. The reader is motivated and rely on different skills interacting: perceptual processing, phonemic processing, recall.

5. Read for a purpose; reading serves a function. [6:184]

M. West conducted extensive research in the field of teaching reading in a foreign language. His scientific works were devoted to an experimental approach to teaching reading in a foreign language. At the same time, in the course of his experiments, the scholar also provided valuable information about the types of reading.

In the initial period, there are the following stages of student perception of a graphic text:

1. The student recognizes the graphic images of the word.

2. Recognizes the meanings.

3. Understands the meaning of the text.

Scientists have studied several types of reading. They are:

1) Analytical/synthetic reading;

2) Introductory/study/observational reading;

3) Prepared/unprepared reading;

4) Reading with/without translation;

5) Reading with a dictionary/without a dictionary;

6) Reading in class/at home;
7) Reading alone/in chorus;

8) Reading silently/loudly;

Now we will try to provide our own thoughts about types of reading mentioned above. Analytical/synthetic reading refers to the analysis and synthesis of linguistic and stylistic means. Analytical reading is such a learning method that is widely used in foreign practice of reading text in a foreign language. Through this kind of reading, students go deeper into the content of the text, which helps them better understand it and analyze familiar and unfamiliar words. The students attempt to obtain information by reading the entire text.

The next type of reading introductory/studying/observational reading. Introductory reading is used by the students to understand the content of the general meaning of the text. At the same time, a full understanding of the text by the students is not expected; they get a brief information about what the text deals with. The text provided for the students must be adapted and its volume should be with small, one page for example.

In this case, the students try to fully understand the content of the text. They pay special attention to every word and every expression in the text. Full understanding of the text can be determined by how the students retell the content of the text in their own words. In studying reading, the students will quickly go through the text. Although he does not fully understand the text, he understands up to half of the information and the main idea of the text. In his book "Methods of Teaching a Foreign Language", J. Jalolov recommends the following order for these types of reading for the stages of education: in the initial stage - introductory reading, attentive reading at one pace, in the middle stage studying reading and familiarization, and in high school - observational reading, introductory and studying reading.

Prepared, unprepared types of reading. The student's reading technique, if he is familiar with the lexical and grammatical material and technical and language difficulties are eliminated in reading, is called prepared reading.

Learning to read without a dictionary is considered one of the important ways of teaching schoolchildren to read, and when reading more complex texts, learning to read using a dictionary is recommended.

Types of reading alone are accustomed to the chorus in order to form the technique of reading. Reading in chorus is often helpful when reading short texts or texts in a poetic form, because there are some difficulties when reading long words in chorus.

Reading loudly is intended mainly to teach reading techniques. With this type of reading information is delivered to the listener. While reading 
silently, on the contrary, the student is busy receiving information.

In addition to this, you can teach reading the text based on the student's area of interest. This kind of reading is called reading for interest (reading for pleasure). With this type of reading, the student understands new words based on the words in the text. The student will be able to highlight the general content of the text not only with the help of a dictionary, but in other ways as well.

Motivational reading - in the process of reading it is required to study the culture, customs and traditions of the country the language of which is being studied. This greatly stimulates the students' interest in the culture of this country and this type of reading increases their motivation.

The text selected for reading must meet the following requirements:

- it must be original or adapted;

- it should be from the works of representatives of classical or modern English or American literature;

- it should be a model of the artistic word in terms of language;

- the text is required to be vital, i.e. it should contain information about the history, customs and other interesting aspects of the life of this nation. [6]

Another type of reading is explained reading. In this case, before reading, the teacher explains the grammar in advance. He also explains the sounds, letters, meanings of words, morphological and syntactic endings.

The success of understanding the text depends on four main factors:

1. The line of students' thoughts;

2. Identification of grammatical phenomena in the text and their recognition;

3. The ability to derive a holistic value and synthesize;

4. As a result of text analysis, students translate obscure words using a dictionary. [6]

In the process of reading the student first of all draws attention to the title of the text and its small parts. Any text, be it small or large, is not recommended to read several times, but certain tasks are performed while reading. If you re-read without performing any tasks, then such reading will not be expedient from a methodological point of view.

Instead of a conclusion, it should be noted that we have produced a brief account of the types of instructions in reading in a foreign language. This information can be covered even more widely. Based on current requirements, not only the above types of reading, but also many other types of reading are widely used in the world.

M. West found that the teachers' attitude towards their teaching methodology was not reliable. Therefore, to overcome the revealed problem, he paid special attention to material selection for the textbooks. "I measured different reading speeds - i.e. reading aloud, in a low voice, fast, word by word and reading in search of a certain viewpoint, i.e. information. I have revealed that before reading activities (questions), performing many pre-text tasks increase the speed of reading. I also found that translating from English to native language can also increase reading speed. This method can be applied to other languages. Reading is not to read aloud with noise, make sounds, but get information or opinions, and ideas," wrote M. West. [1]

His books entitled as "Bilingualism" and "Learning to Read a Foreign Language" became very popular in the UK and the United States of America. An American scientist, Algernon Coleman says the following about the book on "Bilingualism": "This book on teaching youth to foreign languages is the most encompassing book and the great contribution and invention of the author". [3]

M. West's interest in various aspects of foreign language teaching never weakened. In 1929, on the basis of his doctoral thesis "Language in Education" he created yet another new book. In the same period, M. West began to adapt new methodological system in teaching foreign languages and other experiments related to the textbook. "We, as we did in the book "New Method Primer" i.e. through a set of letters, have created a book in order to teach Bengali people to read. In addition, there was a training course for teaching Sanskrit students without complex grammatical rules and at the end of the book was written a separate course for the elementary class, which allowed the teacher to train one class during the teaching in another Class. At that time in elementary schools teachers had to be engaged at once with two classes. At the Imperial Educational Conference held in London, "We said that all school teachers should have experience in spending time on teaching in primary schools and simultaneously working with two classes"”.

In this book, published in Dhaka, which is devoted to the issues of writing materials for reading in teaching foreign languages, M. West provides methodological recommendations on preparation of textbooks, on pronunciation peculiarities, on the samples of discussions and other materials. He expressed his thoughts not only on the information mentioned above about how the Bengali students passed the exam, but also proved that the lack of Bengali lexical units in speech hindered the development of the Bengali language. At the same time, he showed how to adapt the new system of method in contexts to teaching modern languages: at that time the book was written in French, translated and adapted in German, Spanish, Italian and other languages. 
In his article "Modern Languages" (West 1928), written for the British Journal, and later in the article "Modern Language Journal" (West 1930, 1931), written for an American magazine, he stressed that he was passionate about teaching modern foreign languages. Indeed, the new system of methods for learning to read immediately showed its influence on the text-making model for the French and German languages in the USA. At the end of 1920, M. West developed important links here. However, the success of several new methods for M. West became a "double-edged sword". He later said: "In English I created different books, which brought a lot of success". The purpose of M. West was: to develop a system of education where inexperienced teachers work, to create good textbooks, to test them again and again in classes, to help students in training, to cover all expenses on preparation of books and to pay creators of these books to cover their needs. [2]

In conclusion, the contribution of $\mathrm{M}$. West in the field of general education to foreign languages until today is thoroughly explored not only by Dhaka teachers, but also by many in different countries of the world are studying foreign languages, especially leading scientific learning activities. His judgment left an indelible mark on the history of methodology.

As highlighted in the article, during XX century in America methodology of teaching foreign languages was well-known and recognized by many scientists, very important researches were carried out in this sphere. (see: Friz, Lado, etc.). In Russia and Uzbekistan in the second half of XX century plenty of works were created in communicative approach to teaching foreign languages. (see: E.I.Passov, A.A.Leontev). It should be noted that an Uzbek scholar and famous methodologist, professor J.J.Jalolov made great contribution to the development of this research area.

Finally, we can say that retrospective study is of great importance in every sphere. Due to the fact that learning foreign languages is the demand of the time, reading and getting information in English is a topical issue at present. The methodological perspectives of Michael West, which are of huge importance in the world of linguistics, were further developed by leading researchers from different countries which led to the creation of new approaches to teaching foreign languages.

It is possible to provide the names of a number of methodologists - scholars who could be described as the successors of M. West, including professors Folomkina Sofya Kirillovna, Klichnikova Zoe Ivanovna, Berman Iosov Mayseevich, Larsen-DianaFreeman, Jalalov Jamol Jalalovich, Nutall C, Nunan $\mathrm{D}$, Beaumont M. and others. The method of teaching a foreign language, founded by M.West, is still relevant today, since issues of teaching foreign languages are becoming increasingly important in the context of globalization.

\section{REFERENCES}

1. Ali S.N., Q. Zulfaqar. 1969. 'My life in the College'. In Teachers' Training College, Dacca (eds.). 1969, [145]-[167].

2. Anon. 1973. Obituary entitled 'Dr. Michael West: English for foreigners'. The Times, 24 March 1973.

3. Coleman Algernon. 1929. The Teaching of Modern Foreign Languages in the United States: A Report Prepared for The Modern Foreign Language Study. New York: Macmillan.

4. Calcutta University Commission. 1919. Evidence and Documents. Classified Replies ot the Commissioners' Questions 8-12. Report of the Calcutta University Commission, 1917-1919, Volume 10. Calcutta: Superintendent Government Printing, India.

5. Jalalov J.J. "Chet til o'qitish metodikasi": (Foreign language methodology). Tashkent: Ukituvchi, 2012. $2^{\text {nd }}$ ed .438p.

6. Jalalov J.J., Mahkamova G.T., Ashurov Sh.S. English language teaching methodology: for students of specialized departments of the universities and institutes. Tashkent: Fan va texnologiya, 2015. 184p

7. Мильруд Р.П. Методика преподавания английского языка: English teaching methodology: Допущено Министерством образования и науки Российской Федерачии в качестве учебного пособия для студентов высших учебных заведений, обучающихся по специиальности "Иностранных язык" 6 области образования $и$ педагогики. Москва:Дрофа, 2007.2 2-е издание,стереотипное.-С256.

8. West M. 1960. Teaching English in Difficult Circumstances: Teaching English as a Foreign Language with notes on the Technique of Textbook Construction. London: Longmans

9. William Grabe, 2009. Reading in a Second Language moving from theory to Practice: Northern Arizona University Press. 2009 -5p. 